\title{
Characterisation of sphaeractinomyxon types (Cnidaria: Myxozoa) from marine and freshwater oligochaetes in a Portuguese estuary, with the demise of the endocapsa collective group
}

\author{
Sónia Rocha ${ }^{1,2}$, Ângela Alves ${ }^{2}$, Carlos Antunes $^{1,3}$, Pedro Fernandes ${ }^{2}$, Carlos Azevedo $^{1,2}$ and Graça Casal ${ }^{4}$ \\ ${ }^{1}$ Laboratory of Animal Pathology, Interdisciplinary Centre of Marine and Environmental Research (CIIMAR), University of Porto, \\ Portugal; \\ ${ }^{2}$ Laboratory of Cell Biology, Institute of Biomedical Sciences Abel Salazar (ICBAS), University of Porto, Portugal; \\ ${ }^{3}$ Aquamuseu do Rio Minho, Vila Nova de Cerveira, Portugal; \\ ${ }^{4}$ University Institute of Health Sciences \& Institute of Research and Advanced Training in Health Sciences and Technologies \\ (CESPU), Gandra, Portugal
}

\begin{abstract}
Six types of sphaeractinomyxon are reported from the coelomic cavity of oligochaetes collected from the Minho River estuary in northern Portugal. Four new types are morphologically and molecularly described from freshwater species belonging to the genera Psammoryctides Hrabě and Potamothrix Vejdovský et Mrázek in the upper estuary, thus significantly increasing the number of known freshwater sphaeractinomyxon. In the lower estuary, sphaeractinomyxon types 8 and 10 of Rangel et al. (2016) are recorded infecting the marine oligochaete Tubificoides pseudogaster (Dahl). A single specimen of T. pseudogaster further displayed infection by one of the four new types found in the upper estuary, suggesting the involvement of sphaeractinomyxon in the life cycles of myxosporean species that infect migratory fish hosts. The acquisition of these second hosts is proposed to have allowed the myxosporean counterparts of sphaeractinomyxon to cross environmental barriers and conquer new habitats. Phylogenetic analyses of the SSU rRNA gene reveal the four new types clustering within the monophyletic clade of mugiliform-infecting myxobolids, strengthening the previously proposed involvement of the sphaeractinomyxon collective group in the life cycles of this specific group of myxosporeans. Endocapsa types also cluster within the latter clade, having actinospores that differ from those of sphaeractinomyxon only in the presence of valvular swellings that do not change when in contact with water. In this study, however, one type was found displaying actinospores with and without valvular swellings in the same oligochaete specimen. This overlap in actinospore morphology is given as grounds for the demise of the endocapsa collective group.
\end{abstract}

Keywords: Myxosporea; actinospore; life cycle; Annelida; SSU rRNA gene; Minho River

Infection of aquatic oligochaetes by actinospores was first reported by Štolc (1899), who described Synactinomyxon tubificis, Triactinomyxon ignotum and Hexactinomyxon psammoryctis developing in tubificids collected from the Vltava River in the Czech Republic. In the years that followed this discovery, the acquisition of knowledge of actinosporean infections was relatively limited, due not only to low prevalence of infection, but possibly also because they were thought to have little direct economic significance.

In 1984, however, Wolf and Markiw (1984) demonstrated that the life cycle of Myxobolus cerebralis Hofer, 1903, an economically important myxosporean parasite of salmonid fishes, developed triactinomyxon actinospores in the gut epithelium of the oligochaete Tubifex tubifex (Müller). This discovery led to the demise of the class Acti- nosporea (see Kent et al. 1994), but simultaneously boosted interest in the study of actinospores as life cycle stages of the Myxosporea.

Until the invalidation of the Actinosporea, six sphaeractinomyxon had been described: S. stolci, S. gigas, S. danicae, S. ilyodrili, S. amanieui and S. rotundum (Caullery and Mesnil 1904, Granata 1923, Georgevitch 1938, Jírovec 1940, Puytorac 1963, Marques 1984). These types were named following the binomial nomenclature system and described mainly based on the morphological characters of their actinospores, which were represented in schematic drawings.

In the years that followed, Sphaeractinomyxon types 1 and 2 of Hallett et al. (1997), Sphaeractinomyxon ersei Hallett, O’Donoghue et Lester, 1998 and Sphaeractinomyxon leptocapsula Hallett, Erséus et Lester, 1999 were

Address for correspondence: S. Rocha, Laboratory of Cell Biology, Institute of Biomedical Sciences Abel Salazar, University of Porto, Rua Jorge Viterbo Ferreira no. 228, 4050-313 Porto, Portugal; Tel: +351 220428241; Fax: +351 220428090; E-mail: sonia.oliveira.rocha@gmail.com 
described from marine oligochaetes in Hong Kong and Australia (Hallett et al. 1998 1999), but only S. ersei had its SSU rRNA gene sequenced. More recently, 13 sphaeractinomyxon types were morphologically and molecularly described from marine oligochaetes in two Portuguese estuaries (Rangel et al. 2016, Rocha et al. 2019a). Overall, the implementation of molecular methodologies to the study of sphaeractinomyxon types has revealed a higher biodiversity than expected based on morphology-based criteria. In fact, Rangel et al. (2016) showed that actinospore measurements overlap between different types of this collective group, so that the usage of molecular tools is indispensable for the description of new types. Phylogenetic analyses of the SSU rRNA gene further disclosed a possible involvement of the sphaeractinomyxon collective group in the life cycle of mugiliform-infecting myxobolids (Rocha et al. 2019a), which remains to be proved by either molecular inference or experimental transmission studies.

In the late $1990 \mathrm{~s}$, two other collective groups were erected to encompass actinospores that differed from sphaeractinomyxon in specific aspects of their morphology and sporogonic development. The tetraspora collective group comprised types that while displaying the typical morphology of sphaeractinomyxon, developed in groups of four within the pansporocysts, instead of the usual groups of eight. However, recent studies acknowledged this character as too variable to establish distinction between the two collective groups. Consequently, tetraspora was deemed invalid and its two types were transferred to sphaeractinomyxon: sphaeractinomyxon types A and B of Hallett and Lester (1999), formerly classified as Tetraspora discoidea Hallett et Lester, 1999 and Tetraspora rotundum Hallett et Lester, 1999, respectively (Rocha et al. 2019a). These types were described from Australian marine oligochaetes based solely on actinospore morphology (Hallett and Lester 1999), but the first has since then been molecularly reported from its type host.

In turn, endocapsa was erected to encompass actinospores that differed from sphaeractinomyxon only in the presence of valvular swellings that do not change when in contact with water (Hallett et al. 1999). The validity of this collective group was questioned in recent studies (Rangel et al. 2016, Rocha et al. 2019a). Nonetheless, it remained valid and currently comprises four types: Endocapsa rosulata Hallett, Erséus et Lester, 1999 and Endocapsa stepheni Hallett, Erséus et Lester, 1999 from the marine oligochaete Heterodrilus cf. keenani Erséus in Australia (Hallett et al. 1999, 2001); Endocapsa type 1 of Hallett et al. (2001) from immature tubificids, also in Australia; and Endocapsa type of Székely et al. (2007) from the freshwater oligochaete Psammoryctides albicola (Michaelsen) in Syria. Molecular data of the SSU rRNA gene are available for both $E$. rosulata and Endocapsa of Székely et al. (2007).

This study investigated the biodiversity of actinosporean stages infecting freshwater and marine oligochaetes in a northern Portuguese river, from which only one myxosporean species was previously reported (see Rocha et al. 2019b). Among the different collective groups recorded, sphaeractinomyxon was represented by two known and four new types that are described here morphologically and molecularly. The morphological variability found among the actinospores belonging to one of the new types is given as ground for the demise of the endocapsa collective group.

\section{MATERIALS AND METHODS}

\section{Sampling sites and morphological characterisation}

Between 2015 and 2016, mud was collected from two sites in the Minho River, northern Portugal. One site was located in the upper estuary, close to the fyke-nets stationed near the village of Vila Nova de Cerveira $\left(41^{\circ} 56^{\prime} \mathrm{N}\right.$; $\left.08^{\circ} 45^{\prime} \mathrm{W}\right)$. The other was located in the lower estuary, near the village of Caminha $\left(41^{\circ} 52^{\prime} \mathrm{N} ; 08^{\circ} 50^{\prime} \mathrm{W}\right)$. Mud from the upper estuary was collected using a Van Veen grab sediment sampler with an area of $500 \mathrm{~cm}^{2}$ and a maximum capacity of $5,000 \mathrm{~cm}^{3}$, while mud from the lower estuary was collected manually at low tide.

In the laboratory, oligochaetes were isolated from the mud and kept at $4{ }^{\circ} \mathrm{C}$, individually placed into 12 -well plates containing either dechlorinated freshwater or brackish water (15\% salinity), depending on the sampling site from which the mud was obtained. Salinity values at the fyke-nets in the upper estuary are generally below $0.5 \%$, increasing slightly during dry summer periods. In turn, salinity values in the lower estuary range between 15 and $40 \%$ throughout the year (see Dias et al. 2016).

All specimens were examined using the light microscope for the detection of actinosporean stages in internal tissues and cavities. Developmental stages and free actinospores were observed and photographed using an Olympus BX41 light microscope (Olympus, Tokyo, Japan). Morphometry was determined from fresh material, in accordance to Lom et al. (1997). Measurements include the mean value \pm standard deviation (SD), range of variation, and number of measured actinospores $(n)$. All measurements are in micrometres.

\section{Molecular methods}

Genomic DNA from infected oligochaetes was extracted using the GenElute ${ }^{\mathrm{TM}}$ Mammalian Genomic DNA Miniprep Kit (Sigma-Aldrich, St Louis, MO, USA), following the manufacturer's instructions. The DNA was stored in $50 \mu \mathrm{l}$ of TE buffer at $-20^{\circ} \mathrm{C}$ until further use.

The SSU rRNA gene of the actinospores was amplified using both universal and myxosporean-specific primers: the 5 '-end by pairing the primer 18E (5'-CTG GTT GAT CCT GCC AGT-3') (Hillis and Dixon 1991) with ACT3r (5'-ATT GTT CGT TCC ATG-3') (Rocha et al. 2014) and MYX4R (5'-CTG ACA GAT CAC TCC ACG AAC-3') (Hallett and Diamant 2001); the 3'-end by pairing the primers ACT3f (5'-CAT GGA ACG AAC AAT-3') (Hallett and Diamant 2001) and MYX4F (5'-GTT CGT GGA GTG ATC TGT CAG-3') (Rocha et al. 2015) with 18R (5'-CTA CGG AAA CCT TGT TAC G-3') (Whipps et al. 2003).

PCRs were performed in $50 \mu 1$ reactions using $10 \mathrm{pmol}$ of each primer, $10 \mathrm{nmol}$ of each dNTP, $2.0 \mathrm{mM} \mathrm{MgCl}_{2}, 5 \mu \mathrm{l} 10 \times$ Taq polymerase buffer, 1.5 units Taq DNA polymerase (NZYTech, Lisbon, Portugal), and $3 \mu \mathrm{l}$ (approximately 100-150 ng) of genomic DNA. The reactions were run on a Hybaid PxE Thermocycler (Thermo Electron Corporation, Milford, MA, USA), with initial denaturation at $95^{\circ} \mathrm{C}$ for $3 \mathrm{~min}$, followed by 35 cycles of $94^{\circ} \mathrm{C}$ for 
$45 \mathrm{~s}, 53^{\circ} \mathrm{C}$ for $45 \mathrm{~s}$, and $72{ }^{\circ} \mathrm{C}$ for $90 \mathrm{~s}$. The final elongation step was performed at $72^{\circ} \mathrm{C}$ for $7 \mathrm{~min}$.

The 16S rRNA gene of the oligochaete hosts was amplified using the universal primers 16 sar-L (5'-CGC CTG TTT ATC AAA AAC AT-3') and 16sbr-H (5'-CCG GTC TGA ACT CAG ATC ACG T-3') (Palumbi et al. 2002). PCRs were carried out according to the conditions previously mentioned for the actinospores.

Five- $\mu$ l aliquots of the PCR products were electrophoresed through a $1 \%$ agarose $1 \times$ tris-acetate-EDTA buffer (TAE) gel stained with ethidium bromide. Amplified DNA was purified using Puramag ${ }^{\mathrm{TM}}$ magnetic beads coated with carboxylic acid groups (MCLAB, San Francisco, CA, USA). Sequencing reactions were performed with the same primers used for amplification on a BigDye Terminator v3.1 Cycle Sequencing Kit from AppliedBiosystems (Thermo Fisher Scientific, Waltham, MA, USA), and were run on an ABI3700 DNA analyser from AppliedBiosystems (Thermo Fisher Scientific).

\section{Phylogenetic analyses}

The partial SSU rDNA sequences of each sample were aligned using MEGA7 (Kumar et al. 2016) for the construction of assembled sequences. A dataset was generated according to the highest similarity scores obtained using BLAST search. Accordingly, all sphaeractinomyxon types with available SSU rDNA sequences were incorporated in the dataset, as well as closely-related myxosporean and actinosporean stages, i.e., all species of Myxobolus Bütschli, 1882 thus far reported from mullet hosts, Endocapsa rosulata, Endocapsa of Székely et al. (2007) and Triactinomyxon of Székely et al. (2007). Sequences were aligned using MAFFT version 7 available online, and distance estimation was calculated in MEGA7, with the $p$-distance model and all ambiguous positions removed for each sequence pair.

For phylogenetic analyses, other representatives of the clade of myxobolids were included in the dataset, as well as Myxidium lieberkuehni Bütschli, 1882 (X76638) as outgroup species. The final dataset comprised $62 \mathrm{SSU}$ rDNA sequences that were aligned using the software MAFFT version 7 and posteriorly manually edited in MEGA7. Phylogenetic trees were constructed using maximum likelihood (ML), maximum parsimony (MP) and Bayesian inference (BI). ML and MP analyses were conducted in MEGA7 with bootstrap confidence values calculated from 500 replicates.

ML analyses were performed based on the General Time Reversible model with Gamma distributed rate and Invariant sites $(\mathrm{GTR}+\mathrm{G}+\mathrm{I})$ selected on the basis of the lowest score of Bayesian Information Criterion (BIC) and corrected Akaike Information Criterion (AIC) with the MEGA package. MP analyses were obtained using the Subtree-Pruning-Regrafting algorithm with a search level of 1 and random initial tree addition of 10 replicates.

BI analyses were performed in MrBayes v.3.2.6 (Ronquist and Huelsenbeck 2003), using the general time reversible model with gamma-shaped rate variations across sites (Invgamma) $(\mathrm{GTR}+\mathrm{I}+\Gamma)$. Posterior probability distributions were generated using the Markov Chain Monte Carlo (MCMC) method, with four chains running simultaneously for 500,000 generations. Burn-in was set at $25 \%$, and trees were sampled every 100 generations to compile the majority rule consensus tree.

\section{RESULTS}

\section{Myxozoan survey and overall prevalence of infection of sphaeractinomyxon}

During this study, 4,593 oligochaete specimens were isolated from the sediments collected from the Minho River: 4,016 from the sampling site near the fyke-nets in the upper estuary, and 577 from the lower estuary. Myxozoan infection was found in a total of 61 oligochaetes, with the parasites' developmental stages being located either in the intestinal epithelium or in the coelomic cavity. The actinospores and developmental stages occurring in the intestinal epithelium belonged to the aurantiactinomyxon (4 types), synactinomyxon (2 types) and raabeia (1 type) collective groups. The actinosporean stages developing in the coelomic cavity were all identified as belonging to the sphaeractinomyxon collective group and are reported here.

In total, six different types of sphaeractinomyxon could be distinguished: four constitute new types that are described here, while the other two are known types recorded for the first time in the study area. Identification and characterisation of these types was based on both the morphological traits of mature actinospores (whenever present in the infected oligochaete) and sequences of the SSU rRNA gene. Young developmental stages could only be identified based on molecular data. Overall prevalence of infection of sphaeractinomyxon in the Minho River estuary was determined to be $0.2 \%$ (10 infected in a total of 4,593 oligochaetes examined); $0.1 \%$ in the upper estuary ( 5 infected in a total of 4,016 oligochaetes examined); and $0.9 \%$ in the lower estuary ( 5 infected in a total of 577 oligochaetes examined).

Infected oligochaetes were identified through the combined analysis of morphological features and molecular data of the 16S mitochondrial DNA (mtDNA). In the upper estuary, the freshwater "tubificoid naidids" Limnodrilus hoffmeisteri Claparède, Ilyodrilus templetoni (Southern), Psammoryctides barbatus (Grube), and Potamothrix sp. were identified as the species hosting myxozoan infection. In the lower estuary, only the marine oligochaete Tubificoides pseudogaster (Dahl) was found to be infected. Infection by sphaeractinomyxon, specifically, was determined in specimens of $P$. barbatus (1 type), Potamothrix sp. (2 types), and T. pseudogaster (3 types). Only one of the infected oligochaetes in the upper estuary could not be identified, because it was immature and died in the well plate, showing clear signs of degradation.

\section{Characterisation of four novel sphaeractinomyxon types (Cnidaria: Myxozoa)}

\section{Sphaeractinomyxon type 1}

Figs. 1A-D, 3A,B

D e s c ri p ti o n: Mature actinospores spherical in apical view and ellipsoidal in lateral view, $26.0 \pm 1.1(24-28)$ long $(n=6), 25.0$ $\pm 1.4(22-27)$ wide $(n=8), 24.3 \pm 0.7(23-25)$ in diameter $(n$ $=6$ ). Some actinospores exhibited swellings located laterally in three regions equidistant apart. At centre, three polar capsules, pyriform and symmetric, $5.5 \pm 0.5(4.8-6.2)$ long $(n=10)$ and 4.1 $\pm 0.3(3.6-4.7)$ wide $(n=23)$. Polar tubules with 5 longitudinal coils. Sporoplasm with hundreds of secondary cells. 

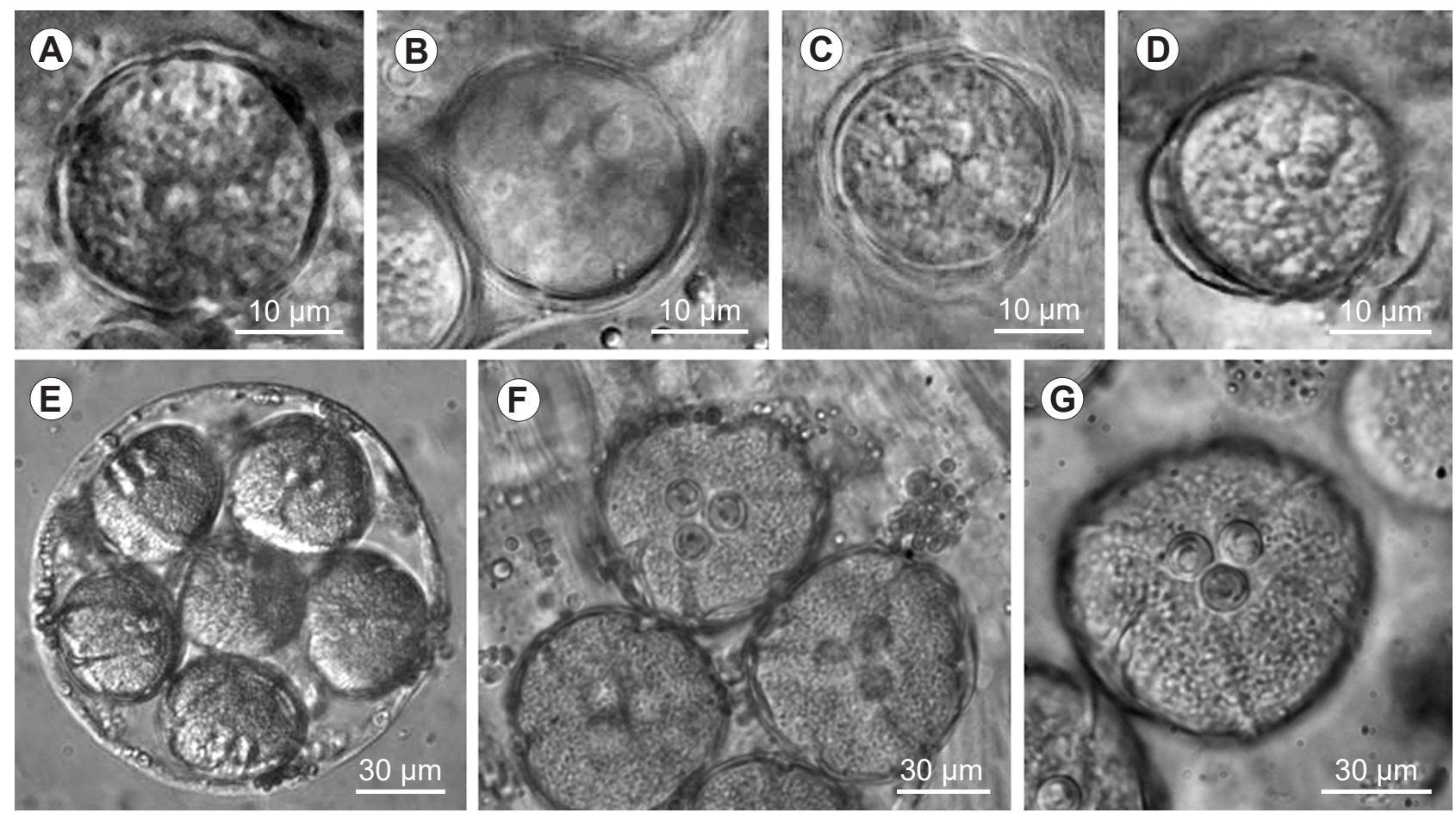

Fig. 1. Light micrographs of new types of sphaeractinomyxon infecting oligochaetes in the Minho River estuary. A-D - Sphaeractinomyxon type 1 from an unidetified oligochaete species in the upper estuary: mature actinospores without valvular swellings, as observed in apical (A) and lateral (B) view; mature actinospores with valvular swellings, as observed in apical (C) and lateral (D) view; E-G - Sphaeractinomyxon type 2 infecting Psammoryctides barbatus (Grube) in the upper estuary: pansporocyst showing six of its eight actinospores developing within (E); group of mature actinospores as observed after rupture of a pansporocyst (F); mature actinospore in apical view (G).

Ho st: Unidentified.

L oc ality: The upper estuary of the Minho River, near Vila Nova de Cerveira, Portugal.

Site of infection: Throughout coelomic cavity.

Prevalence : $0.02 \%$ ( 1 infected of a total of 4,016 oligochaetes examined from the sampling site in the upper estuary).

Deposition of material: One glass slide of the hapantotype deposited in the Type Material Collection of the Laboratory of Animal Pathology, Interdisciplinary Centre of Marine and Environmental Research, Porto, Portugal, reference CIIMAR 2019.48.

Molecular data: One SSU rRNA gene sequence of 2,005 bp long, assembled from the identical partial sequences obtained from the parasitic material in the coelomic cavity of a single infected specimen, and deposited in GenBank with the accession no. MK418446.

Re marks: Morphometry was determined from mature actinospores observed in a single infected host. Morphological comparison revealed no gross similarity to sphaeractinomyxon types that have no available molecular data, i.e., S. stolci Caullery and Mesnil, 1904, S. gigas Granata, 1923, S. danicae Georgevitch, 1938, S. ilyodrili Jírovec, 1940, S. amanieui Puytorac, 1963 and S. rotundum Marques, 1984, Sphaeractinomyxon types 1 and 2 of Hallett et al. (1997), and Sphaeractinomyxon type B of Hallett and Lester (1999). Morphological similarity was also not found in relation to the two endocapsa types that lack molecular data, i.e., Endocapsa stepheni and Endocapsa type 1 of Hallett et al. (2001). The sequence obtained for the parasite did not match any of the SSU rDNA sequences currently available for myxozoans, being most similar to those comprising the clade of mugiliform-infecting myxobolids (Fig. 5). Distance estimation revealed highest percentage of similarity to Myxobolus spp. reported from the gills, intestine and tail of Mugil cephalus (Linnaeus) from the Mediterranean Sea off Northern Israel (MF118765) (98\%), Sphaeractinomyxon type 3 reported in this study (MK418448) (95\%), and Sphaeractinomyxon type 2 of Rocha et al. (2019a) (MH017877) (95\%). All others presented similarity values lower than $95 \%$, including the Endocapsa of Székely et al. (2007) (DQ473516) (94\%) and E. rosulata (AF306791) (89\%).

\section{Sphaeractinomyxon type 2}

Figs. 1E-G, 3C

Description: Mature actinospores spherical in apical view and ellipsoidal in lateral view, $45.0 \pm 1.1(43-46)$ long $(n=$ $6), 54.0 \pm 2.1(51-57)$ wide $(n=6)$, and $53.0 \pm 4.2(48-58)$ in diameter $(n=6)$. At centre, three polar capsules, pyriform and symmetric, $9.4 \pm 0.6(8.6-11.0)$ long $(n=13)$ and $8.2 \pm$ $0.3(7.8-8.7)$ wide $(n=25)$. Polar tubules with undetermined number of coils. Sporoplasm with hundreds of secondary cells.

Host: Psammoryctides barbatus (Grube) (Annelida, Oligochaeta).

L ocality: The upper estuary of the Minho River, near Vila Nova de Cerveira, Portugal.

Site of infection: Throughout the coelomic cavity.

Prevale n c e : $0.05 \%$ (2 infected of a total of 4,016 oligochaetes examined from the sampling site in the upper estuary).

Deposition of material: Series of phototypes of the hapantotype deposited together with a representative DNA sample in the Type Material Collection of the Laboratory of Animal Pathology, Interdisciplinary Centre of Marine and Environmental Research, Porto, Portugal, reference CIIMAR 2019.49.

Molecular data: One SSU rRNA gene sequence 2,002 bp 

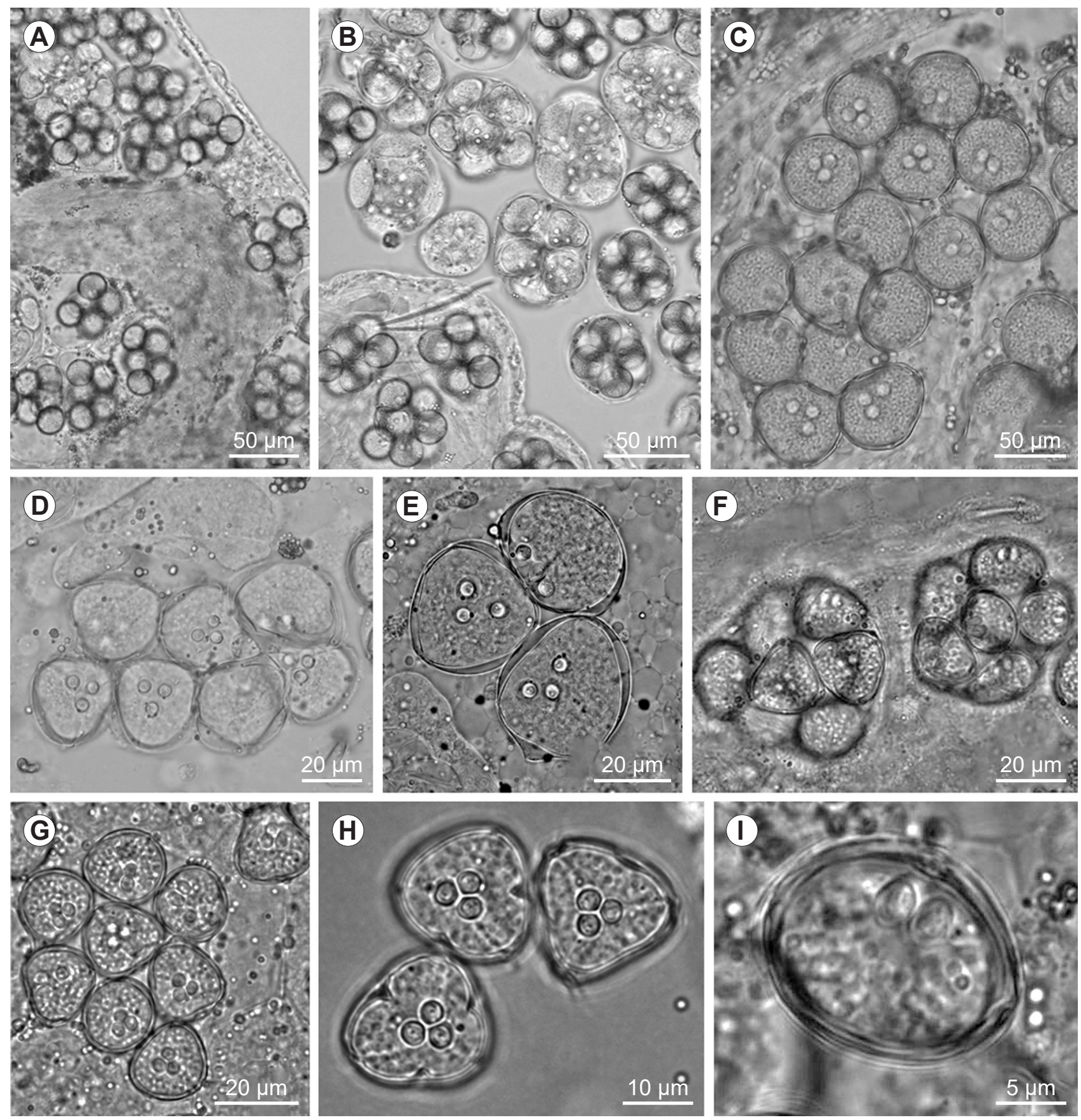

Fig. 2. Light micrographs of new types of sphaeractinomyxon infecting oligochaetes in the Minho River estuary. A-E - Sphaeractinomyxon type 3 found infecting an unidentified Potamothrix sp. in the upper estuary: developmental stages as observed within the coelomic cavity (A) and outside the host's body (B); group of actinospores (C); immature actinospores displaying valvular swellings (D, E); F-I - Sphaeractinomyxon type 4 infecting Tubificoides pseudogaster (Dahl) in the lower estuary: developmental stages in the coelomic cavity (F); group of actinospores as observed after rupture of the pansporocyst $(\mathrm{G})$; mature actinospores in apical view $(\mathrm{H})$; mature actinospore in lateral view (I).

long, representative of two identical sequences obtained separately from the parasitic material in the coelomic cavity of two infected specimens, deposited in GenBank with the accession no. MK418447.

R e m a r k s : Morphometry was determined from one of the two infected hosts, in which fully matured actinospores could be measured. Morphological comparison revealed no gross similarity to sphaeractinomyxon and endocapsa types for which there are no available molecular data. The SSU rDNA se- quence did not match any sequence currently available for myxozoans, being most similar to those comprising the clade of mugiliform-infecting myxobolids (Fig. 5). Distance estimation revealed the highest percentage of similarity to Myxobolus sp. reported from the gills, intestine and tail of M. cephalus from the Mediterranean Sea off northern Israel (MF118765) (95\%); all others presented similarity values lower than $95 \%$. The actinosporean type determined to be genetically most similar (94\%) to the one in study was the Sphaeractinomyxon type 9 of Rangel et al. (2016) (KU569318). 
A
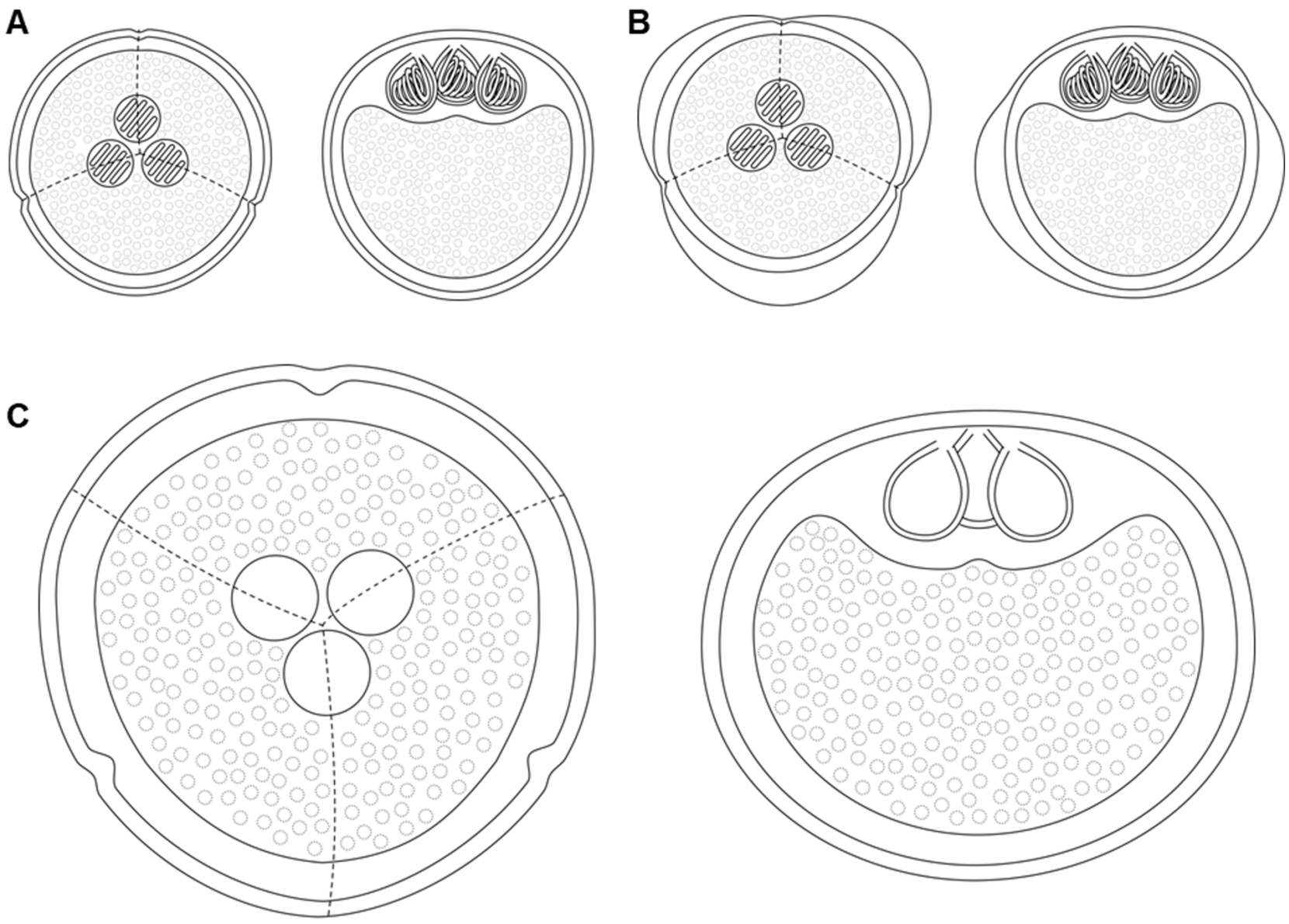

D
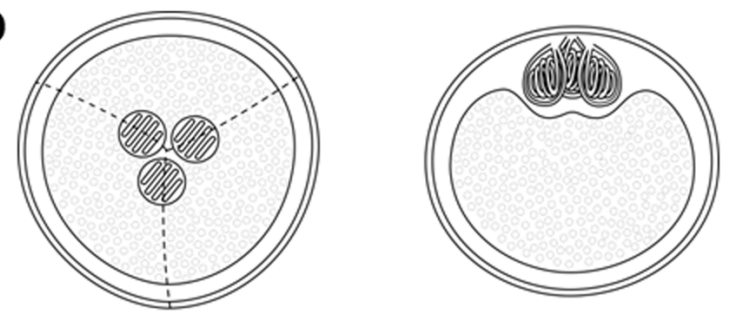

$\mathbf{E}$

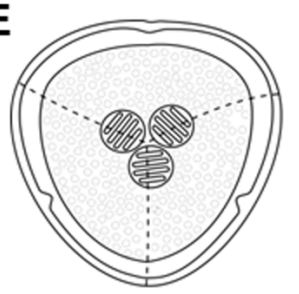

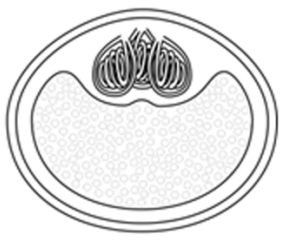

$10 \mu \mathrm{m}$

Fig. 3. Schematic drawings depicting mature actinospores of the new types of sphaeractinomyxon found in the coelomic cavity of freshwater and marine oligochaetes in the estuary of the Minho River, as observed in apical (left) and lateral (right) view. A - Sphaeractinomyxon type 1, actinospores without valvular swellings; B - Sphaeractinomyxon type 1, actinospores displaying valvular swellings; $\mathbf{C}$ - Sphaeractinomyxon type 2; D - Sphaeractinomyxon type 3; E - Sphaeractinomyxon type 4.

\section{Sphaeractinomyxon type 3}

Figs. 2A-E, 3D

Description: Mature actinospores spherical to angular in apical view and subspherical in lateral view, $21.0 \pm 1.0$ (19-23) long $(n=25), 21.3 \pm 0.8(20-23)$ wide $(n=25)$, and $22.0 \pm 1.2(19-24)$ in diameter $(n=20)$. A centre, three polar capsules, pyriform and symmetric, $4.8 \pm 0.4(4.1-5.5)$ long $(n=25)$ and $3.6 \pm 0.2(3.2-4)$ wide $(n=25)$. Polar tubules with 4 longitudinal coils. Sporoplasm with hundreds of secondary cells.

Host: Unidentified "tubificoid naidid" of the genus Potamothrix Vejdovský et Mrázek (Annelida, Oligochaeta).

Locality: The upper estuary of the Minho River, near Vila Nova de Cerveira, Portugal.
Site of infection: Throughout coelomic cavity.

Preva 1 e n c e : $0.02 \%$ ( 1 infected of a total of 4,016 oligochaetes examined from the sampling site in the upper estuary).

Deposition of material: Series of phototypes of the hapantotype deposited together with a representative DNA sample in the Type Material Collection of the Laboratory of Animal Pathology, Interdisciplinary Centre of Marine and Environmental Research, Porto, Portugal, reference CIIMAR 2019.50.

Molecular data: One SSU rRNA gene sequence 1,971 bp long, assembled from the identical partial sequences obtained from the parasitic material in the coelomic cavity of a single infected specimen, and deposited in GenBank with the accession no. MK418448. 

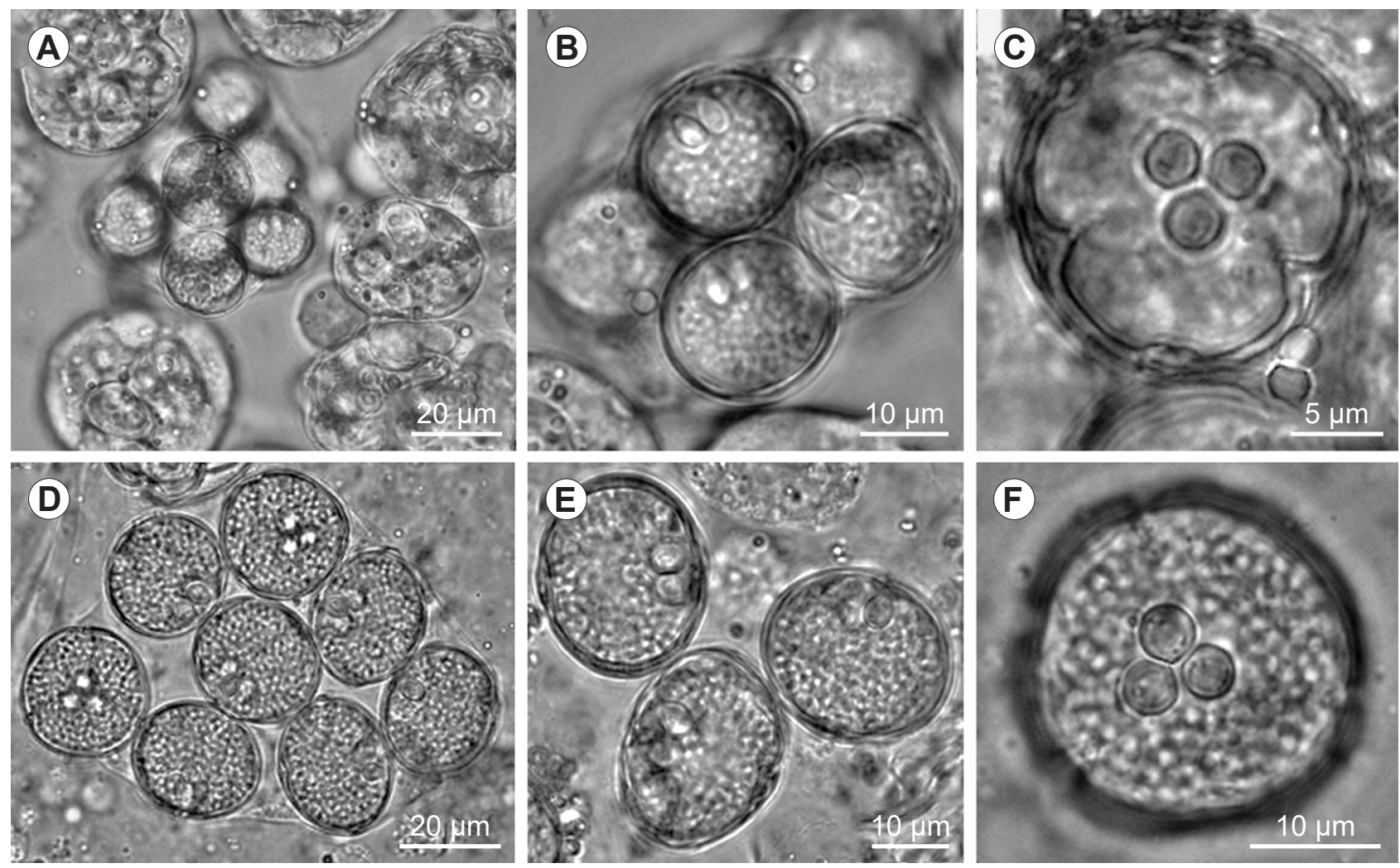

Fig. 4. Light micrographs of the known types of sphaeractinomyxon found infecting Tubificoides pseudogaster (Dahl) in the lower estuary of the Minho River. A-C - Sphaeractinomyxon type 8 of Rangel et al. (2016a): developmental stages in the coelomic cavity (A); pansporocyst showing three mature actinospores in lateral view (B); mature actinospore in apical view (C); D-F - Sphaeractinomyxon type 10 of Rangel et al. (2016a): pansporocyst containing eight mature actinospores (D); mature actinospores in lateral view (E); and mature actinospore in apical view (F).

R e m a rk s : Morphometry was determined from mature actinospores observed in a single infected host. Morphological comparison to sphaeractinomyxon and endocapsa types for which there are no available molecular data revealed some morphometric similarity to S. leptocapsula. The latter, however, differs from the type described here in the triangular shape of its actinospores (see Hallett et al. 1999). The sequence obtained for the parasite did not match any of the SSU rDNA sequences currently available for myxozoans, being most similar to those comprising the clade of mugiliform-infecting myxobolids (Fig. 5). Distance estimation revealed highest percentage of similarity (99\%) to Myxobolus sp. reported from the gills, intestine and tail of $M$. cephalus from the Mediterranean Sea off northern Israel (MF118765), and to the Sphaeractinomyxon type 1 reported in this study (MK418446) (96\%). All others presented similarity values lower than $95 \%$.

\section{Sphaeractinomyxon type 4}

Figs. 2F-I, 3E

Description: Mature actinospores triangular in apical view and ellipsoidal in lateral view, $16.4 \pm 0.8(15-18)$ long $(n=25)$, $20.0 \pm 0.7$ (19-21) wide $(n=25)$, and $20.0 \pm 0.6(19-21)$ in diameter $(n=25)$. At centre, three polar capsules, pyriform and symmetric, $4.5 \pm 0.4(4.0-5.3)$ long $(n=25)$ and $3.2 \pm 0.2(3-3.3)$ wide $(n=25)$. Polar tubules with 3 to 4 longitudinal coils. Sporoplasm with hundreds of secondary cells.

H o s t s : Unidentified tubificoid naidid of the genus Potamothrix Vejdovský et Mrázek (Annelida, Oligochaeta), and Tubificoides pseudogaster (Annelida, Oligochaeta).
L o c a li ty: The Minho River; upper estuary near Vila Nova de Cerveira and lower estuary near Caminha, Portugal.

Site of infection: Throughout coelomic cavity.

P r e va l e n c e : Overall prevalence of infection 0.04\% (2 infected of a total of 4,593 oligochaetes examined from the Minho River estuary): $0.02 \%$ in the upper estuary ( 1 infected in a total of 4,016 oligochaetes examined); $0.2 \%$ in the lower estuary (1 infected in a total of 577 oligochaetes examined).

Deposition of material: Series of phototypes of the hapantotype deposited together with a representative DNA sample in the Type Material Collection of the Laboratory of Animal Pathology, Interdisciplinary Centre of Marine and Environmental Research, Porto, Portugal, reference CIIMAR 2019.51.

Molecular data: One SSU rDNA sequence 2,025 bp long, representative of two identical sequences separately obtained from the parasitic material in the coelomic cavity of two infected specimens, and deposited in GenBank with the accession no. MK418449.

R e m a r k s: Morphometry was determined from one of the two infected hosts (T. pseudogaster), in which fully matured actinospores could be measured. Morphological comparison revealed no gross similarity to sphaeractinomyxon and endocapsa types for which there are no available molecular data. The sequence obtained for the parasite did not match any of the SSU rDNA sequences currently available for myxozoans, being most similar to those comprising the clade of mugiliform-infecting myxobolids (Fig. 5). Distance estimation revealed highest percentage of similarity to (99\%) Myxobolus sp. reported from the gills, intestine and tail of M. cephalus from the Mediterranean Sea 


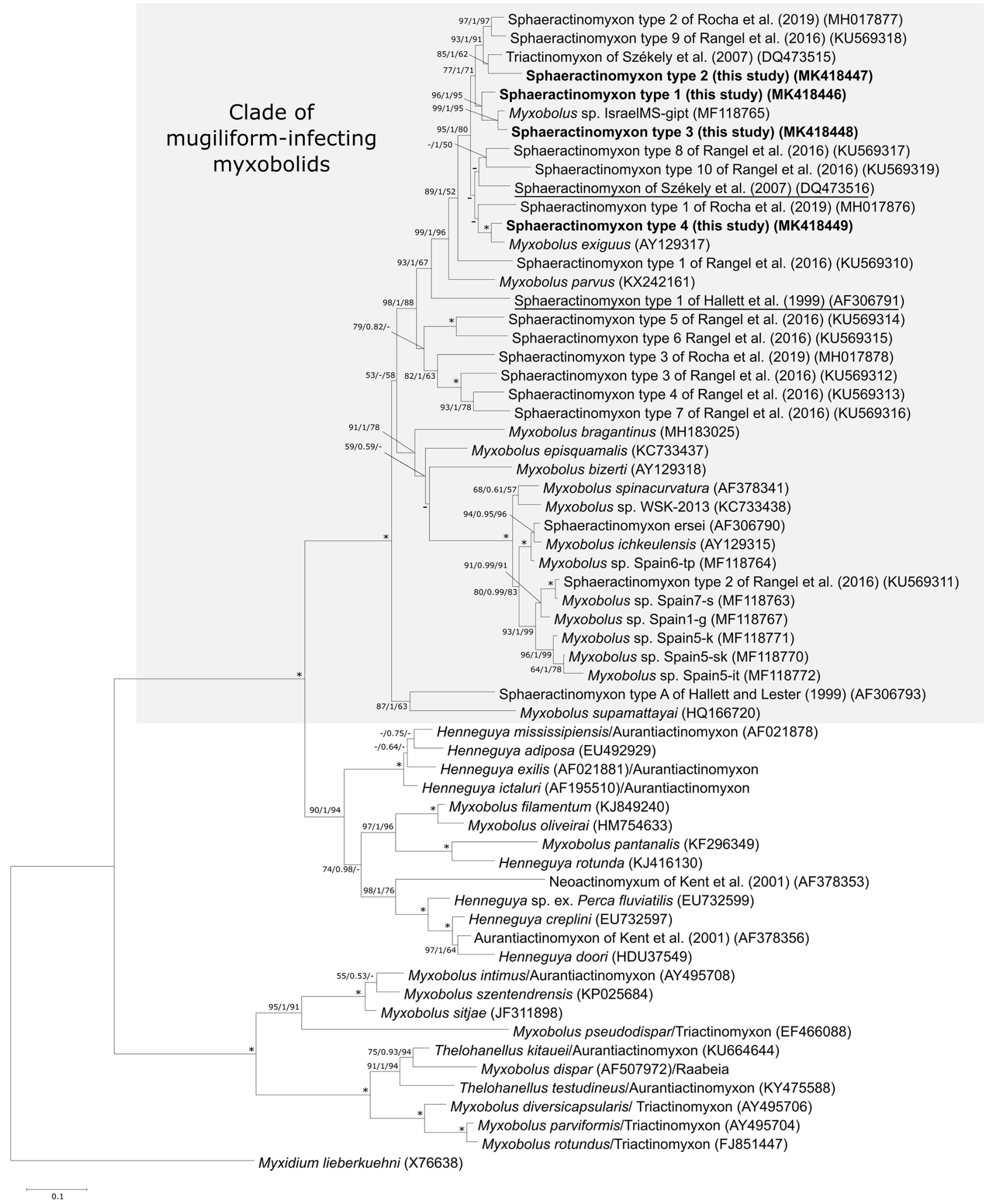

Fig. 5. Tree topology resulting from the maximum likelihood analysis of the SSU rDNA sequences of 62 selected myxosporeans, rooted to Myxidium lieberkuhni (Bütschli, 1982). Numbers at the nodes represent ML bootstrap values/BI posterior probabilities/MP bootstrap values; asterisks represent full support in all methodologies; dashes represent poorly resolved nodes or a different branching pattern. New SSU rDNA sequences are in bold; SSU rDNA sequences of the former Endocapsa are underlined. 
off northern Israel (MF118765); all others presented similarity values lower than $95 \%$. This actinosporean type was genetically most similar to Sphaeractinomyxon type 1 also reported here (MK418446) (95\%).

\section{Record of two previously known sphaeractinomyxon types}

\section{Sphaeractinomyxon type 8 of Rangel et al. (2016)}

Fig. 4A-C

Description: Mature actinospores spherical in apical and lateral view, $18.0 \pm 0.3(18-19)$ long $(n=25), 19.0 \pm 0.5$ (18-20) wide $(n=25)$, and $19.0 \pm 0.3(19-20)$ in diameter $(n=$ $25)$. At centre, three polar capsules, pyriform and symmetric, $4.3 \pm 0.4(3-5)$ long $(n=25)$ and $3.1 \pm 0.2(2.9-3.2)$ wide $(n$ $=25$ ). Polar tubules with 2 to 3 longitudinal coils. Sporoplasm with hundreds of secondary cells.

H o s t: Tubificoides pseudogaster (Annelida, Oligochaeta).

L o c a liti e s : Aveiro estuary $\left(40^{\circ} 40^{\prime \prime} \mathrm{N}\right.$; $\left.08^{\circ} 45^{\prime \prime} \mathrm{W}\right)$, lower estuary of the Minho River near Caminha (new locality); both in Portugal.

Site of infection: Throughout coelomic cavity.

Prevale nce : $0.2 \%$ (1 infected of a total of 577 oligochaetes examined from the sampling site in the lower estuary).

Remarks: The SSU rRNA gene sequence obtained for the sample was $1,959 \mathrm{bp}$ long and was identical with that available for Sphaeractinomyxon type 8 of Rangel et al. (2016) from its original description in the coelomic cavity of $T$. pseudogaster collected from the Aveiro estuary, Portugal. Significant morphometric variation was not recorded in relation to the original description (see Rangel et al. 2016).

\section{Sphaeractinomyxon type 10 of Rangel et al. (2016)}

Fig. 4D-F

Description: Mature actinospores spherical in apical view and ellipsoidal in lateral view, $23.0 \pm 0.7$ (21-24) long $(n=$ 26), $26.0 \pm 0.7(25-27)$ wide $(n=26)$, and $26.0 \pm 0.6(25-27)$ in diameter $(n=30)$. At centre, three polar capsules, pyriform and symmetric, $4.8 \pm 0.2(4.7-5.3)$ long $(n=24)$ and $3.6 \pm$ $0.2(3.3-4.0)$ wide $(n=30)$. Polar tubules with 3 longitudinal coils. Sporoplasm with hundreds of secondary cells.

Ho s t s : Tubificoides pseudogaster (Annelida, Oligochaeta), and Tubificoides insularis (Stephenson) (Annelida, Oligochaeta).

L o c a li t i e s : Aveiro estuary $\left(40^{\circ} 40^{\prime \prime} \mathrm{N} ; 08^{\circ} 45^{\prime \prime} \mathrm{W}\right)$, Alvor estuary near the Algarve Atlantic coast $\left(37^{\circ} 08^{\prime \prime} \mathrm{N} ; 08^{\circ} 37^{\prime \prime} \mathrm{W}\right)$, and the lower estuary of the Minho River near Caminha (new locality); all in Portugal.

Site of infection: Throughout coelomic cavity.

Prevalence: $0.5 \%$ (3 infected of a total of 577 oligochaetes examined from the sampling site in the lower estuary).

R e $\mathrm{m}$ a r k s: The SSU rDNA sequences obtained for this type in three infected host specimens were $\sim 2,010 \mathrm{bp}$ long. They were identical with the sequence available for Sphaeractinomyxon type 10 of Rangel et al. (2016) from its original description in the coelomic cavity of the same host, T. pseudogaster, in the Aveiro estuary, Portugal. Significant morphometric variation was not recorded in relation to the original description of this type, nor to its report from T. insularis in the Alvor estuary, near the Algarve Atlantic coast (see Rangel et al. 2016, Rocha et al. 2019a).

\section{Phylogenetic analyses}

ML, BI and MP analyses produced similar tree topologies and revealed all new SSU rDNA sequences obtained in this study clustering within the clade of mugiliform-infecting myxobolids (Fig. 5), alongside all Myxobolus spp. thus far reported from mullet hosts, as well as all other types of the sphaeractinomyxon and endocapsa collective groups with available molecular data. The Triactinomyxon type of Székely et al. (2007) (DQ473515) was also positioned within this clade.

\section{DISCUSSION}

In this study, actinosporean infection by members of the sphaeractinomyxon collective group was found in the coelomic cavity of both freshwater and marine oligochaetes inhabiting the Minho River estuary. Four new types are described here, whereas two others were identified as being Sphaeractinomyxon types 8 and 10 of Rangel et al. (2016). These two latter types were originally described from specimens of Tubificoides pseudogaster collected from the Aveiro estuary (Portugal) (Rangel et al. 2016), about 180 $\mathrm{km}$ south from our sampling location in the Minho River. The Sphaeractinomyxon type 10 of Rangel et al. (2016) was also reported from a wetland system in the Western Algarve (see Rocha et al. 2019b), which is located about $700 \mathrm{~km}$ south from our sampling location.

The application of molecular tools to the study of actinosporean stages has revealed that the morphological characterisation of actinospores is important but insufficient for the description of new types (see Hallett et al. 2002, 2004, Eszterbauer et al. 2006). In the case of sphaeractinomyxon, studies show that actinospore measurements overlap between molecularly different types that may occur in the same oligochaete host species (see Rangel et al. 2016).

As such, the new and known types reported here were described using a combination of morphological and molecular data. Although the actinospores of the four new types differed amongst each other in their overall morphometry, a high morphological similarity was found between the actinospores of the new Sphaeractinomyxon type 4 and those of the Sphaeractinomyxon type 8 of Rangel et al. (2016) (Table 1). Both these types were observed developing in the coelomic cavity of specimens of T. pseudogaster collected from the lower estuary of the Minho River and, therefore, could only be distinguished through comparison of their respective SSU rDNA sequences. Consequently, our results strengthen the contention that the acquisition of molecular information is indispensable for both the characterisation of new types and proper identification of known types.

Oligochaete hosts were also identified through the combined analysis of morphological traits and molecular information of the $16 \mathrm{~S}$ locus. Recognition at the species-level, however, was only achieved for the freshwater oligochaete Psammoryctides barbatus, identified as the host of Sphaeractinomyxon type 2 in the upper estuary, and the marine oligochaete $T$. pseudogaster, identified as the host of the new Sphaeractinomyxon type 4 and Sphaeractinomyxon types 8 and 10 of Rangel et al. (2016) in the lower estuary. 
Table 1. Actinospore morphometry of the sphaeractinomyxon types reported here from oligochaetes in the River Minho, Portugal.

\begin{tabular}{lcccccc}
\hline Sphaeractinomyxon types & SL & SW & SD & PCL & PCW & PTc \\
\hline Type 1 (this study) & $26.2 \pm 1.1(24-28)$ & $24.9 \pm 1.4(22-27)$ & $24.3 \pm 0.7(23-25)$ & $5.5 \pm 0.5(4.8-6.2)$ & $4.1 \pm 0.3(3.6-4.7)$ & 5 \\
Type 2 (this study) & $45.0 \pm 1.1(43-46)$ & $53.7 \pm 2.1(51-57)$ & $52.7 \pm 4.2(48-58)$ & $9.4 \pm 0.6(8.6-10.6)$ & $8.2 \pm 0.3(7.8-8.7)$ & - \\
Type 3 (this study) & $20.5 \pm 1.0(19-23)$ & $21.3 \pm 0.8(20-23)$ & $21.7 \pm 1.2(19-24)$ & $4.8 \pm 0.4(4.1-5.5)$ & $3.6 \pm 0.2(3.2-4.0)$ & 4 \\
Type 4 (this study) & $16.4 \pm 0.8(15-18)$ & $19.9 \pm 0.7(19-21)$ & $19.7 \pm 0.6(19-21)$ & $4.5 \pm 0.4(4.0-5.3)$ & $3.2 \pm 0.2(3.0-3.3)$ & $3-4$ \\
Type 8 of Rangel et al. (2016a) & $18.4 \pm 0.3(18-18)$ & $19.4 \pm 0.5(18-20)$ & $19.3 \pm 0.3(19-20)$ & $4.3 \pm 0.4(3.2-5.2)$ & $3.1 \pm 0.2(2.9-3.2)$ & $2-3$ \\
Type 10 of Rangel et al. (2016a) & $22.7 \pm 0.7(21-24)$ & $26.1 \pm 0.7(25-27)$ & $25.8 \pm 0.6(25-27)$ & $4.8 \pm 0.2(4.7-5.3)$ & $3.6 \pm 0.2(3.3-4.0)$ & 3 \\
\hline
\end{tabular}

$\mathrm{SL}$ - actinospore length in lateral view; SW - actinospore width in lateral view; SD - actinospore diameter in apical view; PCL - polar capsule length; PCW - polar capsule width; PTc - number of polar tubule coils. Measurements are means \pm SD (range), given in $\mu \mathrm{m}$.

In contrast, the oligochaete hosts of Sphaeractinomyxon types 3 and 4 in the upper estuary could only be recognised as belonging to the same unidentified species of the genus Potamothrix. Lastly, it was not possible to morphologically and molecularly identify the oligochaete species infected with Sphaeractinomyxon type 1, because the specimen in question was immature and died in the well plate, showing clear signs of degradation.

Despite more than one type being registered here from the same Potamothrix sp. in the upper estuary, as well from T. pseudogaster in the lower estuary, mixed infections were not observed. This is congruent with previous studies that reported several different actinosporean types from a single oligochaete species, but never taking place simultaneously in the same individual (e.g., El-Mansy et al. 1998, Xi et al. 2013, 2015, Rosser et al. 2014). In fact, a considerable diversity of sphaeractinomyxon types have been reported to infect T. pseudogaster, Tubificoides insularis and Limnodriloides agnes Hrabě in Portuguese estuaries, but concomitant infections were never recorded (see Rangel et al. 2016, Rocha et al. 2019a).

Of the 25 types of sphaeractinomyxon described in the literature, only four have been reported to infect oligochaetes associated with freshwater environments: S. danicae from an Eiseniella sp., probably E. tetraedra (Savigny); S. gigas from Limnodrilus hoffmeisteri; S. ilyodrili from Potamothrix prespaensis (Hrabĕ); and S. rotundum from unidentified tubificids at Latour-bas-Elne and Villeneuve de la Raho, France (Marques 1984). Our study considerably increases the number of sphaeractinomyxon reported from freshwater and further suggests susceptibility of Potamothrix spp. to infection by sphaeractinomyxon.

In brackish/marine environments, species of the genera Tubificoides Lastočkin and Limnodriloides Pierantoni appear to be the more susceptible to infection by sphaeractinomyxon, thus far having been each recognised as hosts for seven different types of this collective group in Portuguese estuaries (see Rangel et al. 2016, Rocha et al. 2019a). Nonetheless, myxozoan surveys targeting brackish/marine invertebrate communities in other geographic locations may reveal other susceptible oligochaete taxa.

Most sphaeractinomyxon types have been reported exclusively from a single host species. Until this study, Sphaeractinomyxon type 10 of Rangel et al. (2016) constituted the only confirmed exception to a strict host specificity of the collective group with molecular evidence of its development in the coelomic cavity of both $T$. pseudo- gaster and T. insularis (see Rocha et al. 2019a). Although Sphaeractinomyxon stolci and Sphaeractinomyxon ersei were also reported from more than one oligochaete species, their identification in different hosts was based solely on morphological criteria and, therefore, remains uncertain. As such, the occurrence of Sphaeractinomyxon type 4 in two distinct oligochaete species of the family Naididae Ehrenberg, more specifically in a freshwater Potamothrix sp. inhabiting the upper estuary and in the marine oligochaete $T$. pseudogaster inhabiting the lower estuary, confirms that sphaeractinomyxon types are not necessarily restricted to a single host species. Moreover, the presence of this type in both a freshwater and a brackish habitat reinforces the potential involvement of the sphaeractinomyxon collective group in the life cycle of myxosporean species that infect migratory fish hosts, probably mullets, as hypothesised by Rocha et al. (2019b).

Holzer et al. (2018) showed that myxozoans diversified massively after entering fish as second hosts, given that the acquisition of this vertebrate group enabled alternative transmission and dispersion strategies that were crucial in the conquest of new habitats. Mullets are catadromous, meaning that they are born in saltwater and then migrate into freshwater, where they grow before returning to the ocean to spawn. In costal and estuarine ecosystems, where these fishes spend a considerable portion of their lives, a zonal distribution of species has been shown to occur according to salinity gradients. Some species, such as the thinlip grey mullet Chelon ramada (Risso), have a higher adaptability to low salinities and water pollution, thus being able to migrate into the upper estuary (Torricelli et al. 1981, Cardona 2006).

In this context, it can be hypothesised that the acquisition of mullets as second hosts would have allowed the myxosporean counterparts of sphaeractinomyxon to potentially cross environmental barriers and conquer new habitats, whenever a susceptible host could be found in the invertebrate community. The presence of Sphaeractinomyxon type 10 of Rangel et al. (2016) in three Portuguese estuaries (Rangel et al. 2016, Rocha et al. 2019a) further corroborates the crucial role of the vertebrate host in the geographic dissemination of myxosporean parasites.

Individual values of prevalence of infection were determined to be lower than $1 \%$ for all types reported here. These values are in accordance with those reported in previous studies for other types of sphaeractinomyxon, as well as for types of other actinosporean collective groups 
(e.g., Hallett et al. 1999, Székely et al. 2007, Xi et al. 2015, Rocha et al. 2019b). In turn, the overall prevalence of infection of sphaeractinomyxon determined in this study was significantly lower than that reported in previous myxozoan surveys of Portuguese estuaries (see Rangel et al. 2016, Rocha et al. 2019a), which can be correlated to the sampling sites that were chosen in the Minho River.

Other studies collected oligochaetes solely from lower estuaries, while our efforts were divided between two sampling sites, one of which was located in freshwater. Indeed, overall prevalence of infection was noted to be significantly higher in the lower estuary than in the upper estuary, which is consistent with the involvement of sphaeractinomyxon in the life cycles of migratory fish hosts. As previously mentioned, migratory fish spend considerable portions of their lives in brackish environments and, therefore, are more prone to acquire myxozoan infection from the invertebrate communities settled in the lower estuaries.

Thus, further sampling of oligochaetes from the lower estuary of the Minho River will probably reveal a higher diversity of the sphaeractinomyxon collective group. Considering that the sphaeractinomyxon types described here are expected to be counterparts in the life cycles of myxosporean parasites, future research in the Minho River and other Portuguese estuaries should also aim to sample potential fish hosts, namely mullets. To date, Myxobolus exiguus Thélohan, 1895 constitutes the only myxosporean parasite that has been reported from the Minho River, more specifically from the visceral peritoneum of the thinlip grey mullet C. ramada (Rocha et al. 2019b).

The phylogenetic analysis performed in this study showed the new types described here, both freshwater and marine, clustering alongside all other members of the sphaeractinomyxon collective group within the mugiliform-infecting clade of myxobolids (Fig. 5), in accordance with the study of Rocha et al. (2019a). Following the demise of the tetraspora collective group and reassignment of its types to sphaeractinomyxon, only three other actinosporean stages cluster within this mugiliform-infecting clade: Endocapsa rosulata, Endocapsa of Székely et al. (2007), and Triactinomyxon of Székely et al. (2007).

The endocapsa collective group was erected to encompass actinospores that differ morphologically from sphaeractinomyxon only by having irregular processes in the form of swellings that do not change when in contact with water (Hallett et al. 1999). The microscopic observations performed in this study, however, revealed the presence of actinospores with and without valvular swellings in the coelomic cavity of the oligochaete host displaying infection by the new Sphaeractinomyxon type 1. Therefore, casts doubts upon the validity of this morphological criterion for distinguishing between sphaeractinomyxon and endocapsa. Immature actinospores displaying valvular swellings were further observed as part of the development of the other types described here (see Fig. 2D,E). This is congruent with the observations of Rangel et al. (2016), who reported immature sphaeractinomyxon actinospores often displaying valvular swellings similar to those described for endocapsa. These authors also acknowledged that dehydration of mature actinospores caused the sporoplasm to concentrate centrally, leading to the formation of swellings.

A more in-depth look at the available literature further evidences the tenuous distinction between the sphaeractinomyxon and endocapsa collective groups. For instance, Hallett et al. (1999) reported actinospores reminiscent of the original type, Endocapsa rosulata, but without valvular swellings (typical sphaeractinomyxon by default), developing in oligochaetes collected from the same locality. Similarly, the single lobe-like swelling of Endocapsa stepheni was reported to be visible in some actinospores in situ (Hallett et al. 1999). Overall, the figures provided in the description of Endocapsa of Székely et al. (2007) show degradation of the actinospores and, therefore, do not give support to the group. Actinospores of Sphaeractinomyxon gigas were reported to form a double trigonal pyramid, with rounded faces, which can be part of an ellipse (Marques 1984).

Thus, it can be stated that the presence/absence of valvular swellings in the actinospores constitutes a morphological character unsuitable for differentiation between sphaeractinomyxon and endocapsa. The existence of the endocapsa collective group is further questioned by phylogenetic analyses of the SSU rRNA gene which, similarly to the ones performed in this study, show all endocapsa and sphaeractinomyxon types with available molecular data consistently clustering together within a myxobolid clade previously suggested to have a monophyletic origin (Rocha et al., 2019a, b).

Considering all the above, we suggest that endocapsa be deemed invalid and its types transferred to sphaeractinomyxon: E. rosulata becomes Sphaeractinomyxon type 1 of Hallett et al. (1999), E. stepheni becomes Sphaeractinomyxon type 2 of Hallett et al. (1999), Endocapsa type of Hallett et al. (2001) becomes Sphaeractinomyxon type of Hallett et al. (2001), and Endocapsa type of Székely et al. (2007) becomes Sphaeractinomyxon type of Székely et al. (2007).

The evolution of myxozoans and their invertebrate hosts has been shown to be highly congruent, namely because oligochaetes and polychaetes are the definitive and most ancient hosts of this parasitic group (Holzer et al. 2018). As such, future comprehensive revisions of some actinosporean collective groups may be necessary in order to more acurately reflect current phylogenetic and morphological information.

Acknowledgments. The authors acknowledge the editorial assistance given by Miguel Pereira. The work here presented was financially supported by Fundação para a Ciência e a Tecnologia (Lisbon, Portugal) within the scope of the PhD fellowship grant attributed to S. Rocha (SFRH/BD/92661/2013) through the programme QREN-POPH/FSE; and the Eng ${ }^{\circ}$ António de Almeida Foundation (Porto, Portugal). It complies with the current laws of the country in which it was performed. 


\section{REFERENCES}

CARDona L. 2006: Habitat selection by grey mullets (Osteichthyes: Mugilidae) in Mediterranean estuaries: the role of salinity. Sci. Mar. 70: 443-455.

Caullery M., Mesnil F. 1904: Sur un type nouveau (Sphaeractinomyxon stolci n. g. n. sp.) d'Actinomyxidies, et son développement. C. R. Seances Soc. Biol. Fil. 56: 408-410.

Dias E., Morais P., Cotter A.M., Antunes C., Hoffman J.C. 2016: Estuarine consumers utilize marine, estuarine and terrestrial organic matter and provide connectivity among these food webs. Mar. Ecol. Prog. Ser. 554: 21-34.

El-Mansy A., Székely C., Molnár K. 1998: Studies on the occurrence of actinosporean stages of fish myxosporeans in a fish farm of Hungary, with the description of triactinomyxon, raabeia, aurantiactinomyxon and neoactinomyxon types. Acta Vet. Hung. 46: 259-284.

Eszterbauer E., Marton S., Rácz O.Z., Letenyei M., MolNÁR K. 2006: Morphological and genetic differences among actinosporean stages of fish-parasitic myxosporeans (Myxozoa): difficulties of species identification. Syst. Parasitol. 65: 97-114.

Georgevitch J. 1938: Sur Sphaeractinomyxon danicae n. sp., Actinomyxidae parasite d'un Oligochète du lac d'Ochrida. C. R. Acad. Sci., Paris 207: 250-251.

Granata L. 1923: Richerche sugli Attinomissidi. III. Sphaeractinomyxon gigas $\mathrm{n}$. sp. Mon. Zool. Ital. 34: 64-68.

Hallett S.L., Atkinson S.D., El-Matbouli M. 2002: Molecular characterisation of two aurantiactinomyxon (Myxozoa) phenotypes reveals one genotype. J. Fish Dis. 25: 627-631.

Hallett S.L., Atkinson S.D., Erséus C., El-Matbouli M. 2004: Molecular methods clarify morphometric variation in triactinomyxon spores (Myxozoa) released from different oligochaete hosts. Syst. Parasitol. 57: 1-14.

Hallett S.L., Diamant A. 2001: Ultrastructure and small-subunit ribosomal DNA sequence of Henneguya lesteri n. sp. (Myxosporea), a parasite of sand whiting Sillago analis (Sillaginidae) from the coast of Queensland, Australia. Dis. Aquat. Org. 46: 197-212.

Hallett S.L., Erséus C., Lester R.J.G. 1997: Actinosporea from Hong Kong marine oligochaete. In: B. Morton (Ed.), Proceedings of the Eight International Marine Biological Workshop: the Marine Flora and Fauna of Hong Kong and Southern China. Hong Kong University Press, Hong Kong, 1-7.

Hallett S.L., Erséus C., Lester R.J.G. 1999: Actinosporeans (Myxozoa) from marine oligochaetes of the Great Barrier Reef. Syst. Parasitol. 44: 49-57.

Hallett S.L., Erséus C., O’Donoghue P.J., Lester R.J.G. 2001: Parasite fauna of Australian marine oligochaetes. Mem. Queensl. Mus. 46: 555-576.

Hallett S.L., Lester R.J.G. 1999: Actinosporeans (Myxozoa) with four developing spores within a pansporocyst: Tetraspora discoidea $\mathrm{n}$. g. n. sp. and Tetraspora rotundum n. sp. Int. J. Parasitol. 29: 419-427.

Hallett S.L., O’Donoghue P.J., Lester R.J.G. 1998: Structure and development of a marine actinosporean, Sphaeractinomyxon ersei $\mathrm{n}$. sp. (Myxozoa). J. Euk. Microbiol. 45: 142-150.

Hillis D.M., Dixon M.T. 1991: Ribosomal DNA: molecular evolution and phylogenetic inference. Q. Rev. Biol. 66: 411-453.

Holzer A.S., Bartošová-Sojková P., Born-Torrijos A., Lövy A., Hartigan A., Fiala I. 2018: The joint evolution of the Myxozoa and their alternate hosts: a cnidarian recipe for success and vast biodiversity. Mol. Ecol. 27: 1651-1666.

JíroveC O. 1940: Zur Kenntnis einiger in Oligochäten parasitieren den Protisten: II. Ueber Sphaeractinomyxon ilyodrili n. sp. und Neoactinomyxon globosum Granata 1922. Arch. Protistenkd. 94: 212-223.
Kent M.L., Margolis L., Corliss J.O. 1994: The demise of a class of protists - taxonomic and nomenclatural revisions proposed for the protist phylum Myxozoa Grassé, 1970. Can. J. Zool. 72: 932-937.

Kumar S., Stecher G., Tamura K. 2016: MEgA7: Molecular Evolutionary Genetics Analysis Version 7.0 for Bigger Datasets. Mol. Biol. Evol. 33: 1870-1874.

Lom J., McGeorge J., Feist S.W., Morris D., Adams A. 1997: Guidelines for the uniform characterisation of the actinosporean stages of parasites of the phylum Myxozoa. Dis. Aquat. Org. 30: $1-9$.

Marques A. 1984: Contribution a la connaissance des Actinomyxidies: ultrastructure, cycle biologique, systématique. Ph.D. Thesis. Université des Sciences et Techniques de Languedoc, Montpellier, France, 218 pp.

Palumbi S., Martin A., Romano S., McMillan W.O., Stice L., Grabowski G. 2002: The Simple Fools Guide to PCR, Version 2.0. University of Hawaii, Honolulu, 1-45.

Puytorac P.D. 1963: L'ultrastructure des cnidocystes de l'Actinomyxidae: Sphaeractinomyxon amanieui sp. nov. C. R. Acad. Sci. Paris 256: 1594-1596.

Rangel L.F., Castro R., Rocha S., Cech G., Casal G., Azevedo C., Székely C., Cavaleiro F., Santos M.J. 2016: Description of new types of sphaeractinomyxon actinospores (Myxozoa: Myxosporea) from marine tubificid oligochaetes, with a discussion on the validity of the tetraspora and the endocapsa as actinospore collective group names. Parasitol. Res. 115: 2341-2351.

Rocha S., Azevedo C., Oliveira E., Alves Â., Antunes C., Rodrigues P., Casal G. 2019b: Phylogeny and comprehensive revision of mugiliform-infecting myxobolids (Myxozoa, Myxobolidae), with the morphological and molecular redescription of the cryptic species Myxobolus exiguus. Parasitology 146: 479-496.

Rocha S., Casal G., Garcia P., Matos E., Al-Quraishy S., AzEvedo C. 2014: Ultrastructure and phylogeny of the parasite Henneguya carolina sp. nov. (Myxozoa), from the marine fish Trachinotus carolinus in Brazil. Dis. Aquat. Org. 112: 139-148.

Rocha S., Casal G., Rangel L., Castro R., Severino R., Azevedo C., Santos M.J. 2015: Ultrastructure and phylogeny of Ceratomyxa auratae n. sp. (Myxosporea: Ceratomyxidae), a parasite infecting the gilthead seabream Sparus aurata (Teleostei: Sparidae). Parasitol. Int. 64: 305-313.

Rocha S., Rangel L.F., Castro R., Severino R., Azevedo C., Santos M.J., Casal G. 2019a: The potential role of the sphaeractinomyxon collective group (Cnidaria, Myxozoa) in the life cycle of mugiliform-infecting myxobolids, with the morphological and molecular description of three new types from the oligochaete Tubificoides insularis. J. Invertebr. Pathol. 160: 33-42.

RonQuist F., Huelsenbeck J.P. 2003: MrBayes 3: Bayesian phylogenetic inference under mixed models. Bioinformatics 19: $1572-1574$.

Rosser T.G., Griffin M.J., Quiniou S.M., Greenway T.E., Khoo L.H., Wise D.J., Роте L.M. 2014: Molecular and morphological characterization of myxozoan actinospore types from a commercial catfish pond in the Mississippi delta. J. Parasitol. 100: 828-839.

ŠTolC A. 1899: Actinomyxidies, nouveau groupe de Mesozoaires parent des Myxosporidies. Bull. Int. l'Acad. Sci. Bohème. 12: $1-12$.

Székely C., Hallett S.L., Al-Samman A., Dayoub A. 2007: First description of myxozoans from Syria: novel records of hexactinomyxon, triactinomyxon and endocapsa actinospore types. Dis. Aquat. Org. 74: 127-137. 
Torricelli P., Tongiorgi P., Almansi P. 1981: Migration of grey mullet fry into the Arno river: seasonal appearance, daily activity, and feeding rhythms. Fish. Res. 1: 219-234.

Whipps C.M., Adlard R.D., Bryant M.S., Lester R.J., FindLAY V., Kent M.L. 2003: First report of three Kudoa species from eastern Australia: Kudoa thyrsites from mahi mahi (Coryphaena hippurus), Kudoa amamiensis and Kudoa minithyrsites n. sp. from sweeper (Pempheris ypsilychnus). J. Euk. Microbiol. 50: $215-219$.
Wolf K., MARKiw M.E. 1984: Biology contravenes taxonomy in the Myxozoa: new discoveries show alternation of invertebrate and vertebrate hosts. Science 225: 1449-1452.

Xi B.W., Zhang J.Y., Xie J., Pan L.K., Xu P., Ge X.P. 2013: Three actinosporean types (Myxozoa) from the oligochaete Branchiura sowerbyi in China. Parasitol. Res. 112: 1575-1582.

Xi B.W., Zhou Z.G., Xie J., Pan L.K., Yang Y.L., Ge X.P. 2015: Morphological and molecular characterization of actinosporeans infecting oligochaete Branchiura sowerbyi from Chinese carp ponds. Dis. Aquat. Org. 114: 217-228.

Cite this article as: Rocha S., Alves Â., Antunes C., Fernandes P., Azevedo C. and Casal G. 2020: Characterisation of sphaeractinomyxon types (Cnidaria: Myxozoa) from marine and freshwater oligochaetes in a Portuguese estuary, with the demise of the endocapsa collective group. Folia Parasitol. 67: 002. 